\title{
Assessment of Administrative Control Strategies for Quality Assurance in Nigerian Public Secondary Schools
}

\author{
Aja, Sunday Nwambam \\ Department Of Educational Foundations, Faculty of Education, Ebonyi State University, Abakaliki, Nigeria
}

\begin{abstract}
This study was carried out to assess how administrative control strategies are carried for quality assurance in public secondary schools in Ebonyi State. Four research questions guided the study. Descriptive survey reseach design was adopted for the study. All the two thousand nine hundred and ninety two (2992) teachers/principals in the two hundred and twenty one (221) public secondary schools in Ebonyi state were used for the study. Simple random sampling technique was used to select three hundred (300) teachers/principals used for the study. Researcher structured questionnaire was used for data collection. The data collected were analyzed using mean scores. The findings of the study revealed that Ebonyi state public secondary schools are not adequately supervised, educational facilities are not adequately provided and teachers' performance are not adequately appraised for teachers improvement. It was also observed that disciplinary measures are not adequately applied in public secondary schools. Based on the findings, it was recommended that the federal and state inspectorate services should ensure regular supervision and monitoring of public secondary schools to ensure their total compliance with the quality standards, also the secondary education board should ensure that required educational facilities are provided to all public secondary schools. Above all regular appraisal programme should be organized for teachers for their professional growth and overall improvement of instructional delivery in public secondary schools. Finally, principals should ensure that friendly environment is created in their schools to forestall disciplinary problems as well as use appropriate disciplinary measures to handle staff disciplinary matters.
\end{abstract}

Keywords: Administrative control strategies, quality assurance, public secondary school, Ebonyi state, Nigeria

\section{Introduction}

Secondary schools are institutions that provide education services for those who have completed primary schools as well as prepare the students for higher institutions of learning. Secondary schools are very important in the national development because they provide the bulk of manpower needed in most productive processes in any given country. The Federal Republic of Nigeria (FRN, 2004) specified the goals of secondary education to include: to inspire students with a desire for self improvement and achievement of excellence and also to raise a generation of people who can think for themselves. Ogba (2011) added that secondary schools provide the general training necessary for the individuals to acquire skills needed to prepare them for future career challenges. This view holds that secondary education is critical for the achievement of national goals and objectives in Nigeria. It is against this background that this study was conceived to assess how administrative control strategies are carried for quality assurance in public secondary schools in Ebonyi state of Nigeria

\section{Literature Review}

Control is an administrative function which is exercised by the leader in order to regulate activities in an organization and to ensure that what is done is in line with the organizational objectives. Akanni (1987) in Odedeji and Fasasi (2006) defined control as a process of ensuring that actual; direction and performance of the members of an organization are in conformity with the set goals. This implies that the leader is expected to exercise control by monitoring every aspect of the organization to ensure that duties are conducted according to expectations. Control as a management function aims at assuring that results of operations conform as closely as possible to the established norms. It also aims at providing timely information which way be used for the revision of the organizational goals.

Control strategies on the other hand are regulations, procedures and techniques, supervision, discipline and budgeting functions leaders adopt in order to guide and monitor the operation of individual members or group in an organization toward the achievement of the set goal or objectives. This means that in processing the organizational inputs, there is need for an element of control so that the resources are utilized for the purpose they are intended for.

Aderounmu, Jiboyewa and Ejiogu (1988) in Oyediji and Fasasi (2006) opine that control strategies are the policies and rules, meeting, organizational design, performance appraised, budget and technology use in regulating the conduct of organizational business. They maintain that government policies and laws provide guidelines on what should be done in any public and private organizations, while leaders reach the member of the organization through meetings for effective decision making, information dissemination and experience sharing geared towards doing the right things. Organizational design is the structure of the organization that shows position, relationship and role expectations of individuals in their work place. Evaluation or appraisal is the process of determining the quality, worth and standard of anything be it an activity, event, person object or programme. It help at all level of human action, individuals, groups, institutions and government to pass judgment about the appropriateness or in-appropriateness, desirability or otherwise of events, decisions, processes, 


\section{International Journal of Science and Research (IJSR) \\ ISSN (Online): 2319-7064}

Index Copernicus Value (2013): 6.14 | Impact Factor (2015): 6.391

objectives, situations, performances etc (Nworgu, 2010). Performance appraisal provides means of evaluating staff or students in schools. Budget set the basis for allocation of resources to different units of the organization for accountability and effective realization of set goals. Technology is the sum of the methods and materials used for executing programmes or work in the organization. All administrative actions severally and collectively influence human behavior to bring about quality output or performance.

Quality connotes high standard, excellence, very good as applicable to any trait or characteristic of a being or thing. Bateman and Snell (1999) in Omoregie (2005) see quality as conformance to certain standard. They posit that quality in education is the success with which an educational institution provides a conducive environment that enable them achieve the educational goals. This enabling environment could be achieved through application of various processes used in monitoring, evaluating and enhancing educational delivery normally referred to as quality assurance. Administrative control strategies as natural demand in all productive or service oriented enterprises are the tools used by managers to ensure organizational quality. Education industry is not left out since it is concerned with human capacity development which is most valuable and challenging of all productive processes. The importance of quality in education cannot be overemphasized. This is because the school as an agent of education plays a role of a factory for processing illiterate individuals as raw materials into knowledgeable individuals capable of contributing to national development. A good quality education system is one that provides the participants with capabilities they require to become economically productive develop sustainable livelihood, contribute to peaceful and democratic societies and enhance individual well-being.

A quality education is one that satisfies basic learning needs and enriches the lives of learners and their overall experience of living. World education forum 2015 held on 19-22 May, 2015 at Incheon, Republic of Korea maintained that teachers are the key to improving the quality of education as they have a powerful impact on the quality of student teaching and learning which the ultimate goal of any education process are. Quality learning to them is not only essential for meeting people's basic needs, but is also fundamental in fostering the conditions for global peace and sustainable development. They noted with nostalgia that many countries especially the developing countries like Nigeria and the likes are facing an acute shortage of qualified teacher because the serving teachers are poorly and sometimes irregularly paid hence teachers suffer from low social and professional status compared with other professions like medicine, law, engineering etc.

Quality control focuses on the process of producing the products or services with the intent of eliminating problems that might result in defects. This includes the operational techniques and activities which will help to sustain the standard of product or service in other to satisfy given needs. For instance, by establishing minimum standards or bench mark as a regulatory operational guideline for effective quality management of educational institutions. Quality management is the totality of functions involved in the determination and achievement of quality control and assurance. It is otherwise referred to as total quality management (TQM) which consist of many elements such as leadership, information analysis, benchmarking, strategic quality planning, human resource development, quality assurance of products and services and customers satisfaction (Fadakun, 2004). It is based on the overriding importance of quality in the education palace that the need for a study on assessment of how administrative control strategies are carried for quality assurance in public secondary schools becomes is apt.

\section{Statement of the Problem}

The national policy on education in Nigeria represents a bold step at ensuring uniform standard in the education system. Like all policy documents, the national policy on education provides only a framework without detailed directions of how to reach the set goals because it is evolved through a top-down approach. This makes it imperative for various state governments to put in place various measures for achieving the goals of secondary education especially at the institutional levels. Secondary education in Nigeria with the broad goals to prepare individual for useful living within the society and higher education though laudable, live much to be desired. The performance of students in qualifying examination like NECO, WEAC's senior secondary school certificates and JAMB's unified tertiary institution entry examination are grossly poor coupled with rising incidence of examination malpractices. The problem quality in education seems to rely heavily on the teachers because they are directly responsible for the implementation of any educational programme. This may be the reason the then president of Nigeria Olusegun Obasanjo during the inauguration of the Universal Basic Education (UBE) in1999 blamed the falling standard of education in Nigeria on shortage of qualified teachers. It is against this backdrop that the problem of the study is posed as a question thus: how is the administrative control carried for quality control in public secondary schools.

\section{Purpose of the Study}

The main purpose of the study was to assess how administrative control strategies are carried for quality control in public secondary schools in Ebonyi state. Specifically, the study sought to find out:

1) How supervision of instruction is carried out in public secondary schools in Ebonyi state

2) The provision of educational facilities in public secondary schools in Ebonyi state.

3) How teachers' performance is appraised in public secondary schools in Ebonyi State

4) How disciplinary actions are carried out in public secondary school in Ebonyi State.

\section{Significance of the Study}

The findings of the study will be of great importance to the government, school administrators, students and the general 


\section{International Journal of Science and Research (IJSR) \\ ISSN (Online): 2319-7064}

Index Copernicus Value (2013): 6.14 | Impact Factor (2015): 6.391

public. The result of these findings will provide government a road map that will guide her in making policies that will guarantee quality control and assurance in secondary schools. School administrators will be informed through the result of the study on the measures to adopt to bring about improvement in the seemingly decline on standard of secondary education when all the measures suggested in the work are effectively implemented. Students will as well sit up in their studies for a turnaround high academic performance if effective control measures are put in place. Finally, the graduates of secondary schools that will be produced when the result of this study is implemented would contribute to greater productivity and national development.

\section{Scope of the Study}

The study was carried out in Ebonyi state public secondary schools of Nigeria to assess how instructional programme is supervised, educational facilities provided, how teachers' performance is appraised and how disciplinary actions are carried out for quality control in Ebonyi state public secondary schools.

\section{Research Questions}

The following research questions were formulated to guide the study:

1) How is supervision of instruction carried out in public secondary schools in Ebonyi state?

2) How is educational facilities provided in public secondary schools in Ebonyi state?

3) How are teachers' performance appraised in public secondary schools in Ebonyi state?

4) How are disciplinary actions carried out in public secondary schools in Ebonyi state?

\section{Research Methodology}

The study adopted descriptive survey research design. The population of the study comprised all the two thousand nine hundred and ninety (2990) teachers/principals in the two hundred and twenty one (221) public secondary schools in Ebonyi state of Nigeria. Simple random sampling technique was used to select ten (10) teachers (principals inclusive) from the thirty schools chosen across the three education zones in Ebonyi state (Abakaliki, Afikpo and Onueke Zones). This gave a total sample size of three hundred (300) respondents. Researcher-structured questionnaire was used as instrument for data collection. The instrument has two sections (A\&B), section A contains the demographic data of the respondents while section $B$ contains a twenty questionnaire items patterned on a 4-point rating scale to elicit response from respondents using strongly agree (SA)4points, agree (A)- 3points, disagree (D) - 2points and strongly disagree (SD)- I point response options. The instrument was validated by three experts from department of Educational Foundations Ebonyi state university, Abakaliki. The reliability estimate through test re-test method was 0.78 . This figure is high enough to consider the instrument suitable for the study. The instrument was administered personally and collected same by the researcher to ensure a hundred percent return. The data collected were analysed using mean scores.

\section{Results}

The data collected in respect to the research questions were presented and analyzed as shown on the table below:

\section{Research Question One}

How is supervision of instruction carried out in public secondary schools in Ebonyi State?

Table 1: Mean scores of respondents on how supervision of instruction is carried out in public secondary schools.

\begin{tabular}{|c|c|c|c|c|c|c|c|c|c|}
\hline $\mathbf{S} / \mathbf{N}$ & $\mathbf{I t e m}$ statement & $\mathbf{S A}$ & $\mathbf{A}$ & $\mathbf{D}$ & $\mathbf{S D}$ & $\mathbf{N}$ & $\mathbf{F X}$ & $\mathbf{X}$ & $\mathbf{D e c i s i o n}$ \\
\hline 1 & $\begin{array}{c}\text { Education supervisors from ministry of education visit your school for } \\
\text { purposes of quality assurance regularly }\end{array}$ & 240 & 210 & 160 & 90 & 300 & 700 & 2.33 & Disagree \\
\hline 2 & $\begin{array}{c}\text { The principal or a teacher delegated by the principal corrects teacher's notes } \\
\text { of lessons on a weekly basis }\end{array}$ & 200 & 180 & 180 & 100 & 300 & 660 & 2.2 & Disagree \\
\hline 3 & $\begin{array}{c}\text { Heads of department participate in the supervision of instruction by visiting } \\
\text { teachers in the classroom to watch how they teach }\end{array}$ & 220 & 195 & 200 & 80 & 300 & 695 & 2.32 & Disagree \\
\hline 4 & $\begin{array}{c}\text { Officials from secondary education board (SEB) visit your school for } \\
\text { supervision of instruction regularly }\end{array}$ & 240 & 180 & 180 & 100 & 300 & 700 & 2.33 & Disagree \\
\hline 5 & Supervisors help teachers in lesson planning before teaching. & 200 & 210 & 200 & 80 & 300 & 690 & 2.3 & Disagree \\
\hline & Grand mean & & & & & & 2.3 & \\
\hline
\end{tabular}

The result of data analyzed in table one show that the respondents do not agree with item 1-5 which means that in their opinion, inspectors of education do not visit schools regularly for supervision of instruction. Principals or their delegates do not correct teacher's notes of lesson on weekly basis. Heads of departments do not visit teachers in the classroom to watch how they teach. Officials from secondary education board (SEB) do not visit schools regularly for supervision of instruction and supervisors from ministry of education do not help teachers to determine lesson objectives and techniques for teaching. This is evident by the grand mean of 2.3 as can be seen on the table which is below the criterion reference point of 2.5 .

\section{Research question 2}

How are educational facilities provided in public secondary schools in Ebonyi state? 


\section{International Journal of Science and Research (IJSR) \\ ISSN (Online): 2319-7064}

Index Copernicus Value (2013): 6.14 | Impact Factor (2015): 6.391

Table 1: Mean response of respondents on how educational facilities are provided in public secondary schools

\begin{tabular}{|c|c|c|c|c|c|c|c|c|c|}
\hline S/N & Item statement & SA & A & D & SD & N & FX & X & DECISION \\
\hline 6 & $\begin{array}{c}\text { There are enough classroom accommodation for teaching and learning in } \\
\text { this school }\end{array}$ & 200 & 210 & 200 & 80 & 300 & 690 & 2.3 & Disagree \\
\hline 7 & The school library has enough books in all subjects & 160 & 180 & 200 & 100 & 300 & 640 & 2.13 & Disagree \\
\hline 8 & Good source of water is available in this school & 220 & 195 & 160 & 100 & 300 & 675 & 2.25 & Disagree \\
\hline 9 & There are enough equipment in the school science laboratory & 180 & 180 & 150 & 120 & 300 & 630 & 2.1 & Disagree \\
\hline 10 & The school has regular supply of electricity & 120 & 150 & 300 & 70 & 300 & 540 & 1.8 & Disagree \\
\hline & Grand mean & & & & & & & 2.12 & \\
\hline
\end{tabular}

Result of data analyzed in table 2 reveals that the respondents disagreed with item 6-10 as can be seen from the mean scores and grand mean of 2.3 which is below cut off point of 2.5. This implies that educational facilities are not adequately provided in Ebonyi state public secondary schools.

\section{Research Question Three}

How are teachers performance appraised in public secondary schools in Ebonyi state?

Table 3: Mean response of respondents on how teachers performance are appraised in public secondary schools

\begin{tabular}{|c|c|c|c|c|c|c|c|c|c|}
\hline S/N & Item statement & SA & A & D & SD & N & FX & X & DECISION \\
\hline 11 & Teachers are assessed regularly by Ministry of Education & 160 & 180 & 240 & 80 & 300 & 660 & 2.2 & Disagree \\
\hline 12 & Schools provide performance evaluation forms for teachers & 200 & 210 & 160 & 100 & 300 & 670 & 2.23 & Disagree \\
\hline 13 & Teachers are given periodic test for performance evaluation. & 120 & 90 & 200 & 140 & 300 & 550 & 1.83 & Disagree \\
\hline 14 & Teachers participate in general examination for promotion. & 80 & 90 & 240 & 130 & 300 & 540 & 1.8 & Disagree \\
\hline 15 & School board conducts regular performance evaluation test for teachers. & 60 & 75 & 200 & 160 & 300 & 495 & 1.65 & Disagree \\
\hline & Grand mean & & & & & & & 1.94 & \\
\hline
\end{tabular}

The result of data analysis presented in table 3 indicates that the respondents disagreed with item 11-15 as evident in the mean scores. Also the grand mean of 1.94 which is below 2.5 implies that teachers' performance are not adequately appraised in public secondary schools.

\section{Research Question Four}

How are disciplinary actions carried in public secondary schools in Ebonyi state?

Table 4: Mean response of respondents on how disciplinary actions are carried out in public secondary schools.

\begin{tabular}{|c|c|c|c|c|c|c|c|c|c|}
\hline S/N & ITEM STATEMENT & SA & A & D & SD & N & FX & X & DECISION \\
\hline 16 & The principal uses school guidance counselor to control staff behaviour & 80 & 90 & 200 & 150 & 300 & 520 & 1.73 & Disagree \\
\hline 17 & Any staff who goes against the rules is reprimanded orally by the principal & 280 & 240 & 200 & 50 & 300 & 770 & 2.57 & Disagree \\
\hline 18 & The principal sends staff who misbehaves to the staff disciplinary committee & 240 & 240 & 160 & 80 & 300 & 720 & 2.4 & Disagree \\
\hline 19 & When a staff misbehaves, the principal usually give a query & 200 & 240 & 200 & 110 & 300 & 750 & 2.5 & Agree \\
\hline 20 & $\begin{array}{c}\text { The principal usually recommend erring staff to the education board for } \\
\text { punishment }\end{array}$ & 180 & 175 & 220 & 90 & 300 & 665 & 2.22 & Disagree \\
\hline & Grand mean & & & & & & & 1.94 & \\
\hline
\end{tabular}

The result of data anlaysed in table 4 reveals that the respondents agreed with items 17 and19 as disciplinary measures put in place to control staff in secondary schools but disagreed with item 16, 18 and 20. The grand mean of 2.28 which is below the cut-off point of 2.5 is an indicative that disciplinary measures are not adequately put in place for staff control in secondary schools in Ebonyi state.

\section{Summary of Findings}

The findings of this study are summarized as stated hereunder:

1) Supervision of instruction is not carried out effectively in Ebonyi state public secondary schools.

2) Educational facilities are not adequately provided in Ebonyi state public secondary schools.

3) Teachers' performances are not adequately appraised in Ebonyi state public secondary schools.

4) Disciplinary actions are not adequately carried out in Ebonyi state pubic secondary schools.

\section{Discussion of the findings}

Result on research question one, which sought to find out the way supervision of instruction are being carried out in public secondary schools in Ebonyi state revealed that supervision of instruction are not effectively carried out in public secondary schools in Ebonyi state. Affianmgbon, Nwokocha and Okunamiri (2009) assertion collaborated the present study finding when they noted that most administrators of secondary schools have not been providing adequate guidance, direction and assistance that are needed through adequate supervision of staff. It is therefore implicit that staff will not give what they do not have and the quality of education under this condition may not be guaranteed. Supervision of instruction has been one of the most effective quality control measures. This was in line with Madumere (2004) who opined that supervision of instruction is an important strategy in educational institutions used by administrators who want to control their staff and students well to achieve high productivity, because it helps to 


\section{International Journal of Science and Research (IJSR) \\ ISSN (Online): 2319-7064}

Index Copernicus Value (2013): 6.14 | Impact Factor (2015): 6.391

strengthen good working relationship as well as keep the staff in high spirit to perform their duties.

On the educational facilities provided in Ebonyi state public secondary schools, the result indicates that they are not adequately provided. There is no gain stating the obvious that absence of facilities such as accommodation, classroom, library and laboratory equipment, water, electricity as well as sports facilities will greatly erode the quality of education. This findings is in tandem with federal ministry of education (2009) report which among other things revealed that the state of secondary school buildings are in terrible state of despair and other school facilities are inadequate and in short supply. Azih (2008) opined that the link between available educational facilities, the programme curriculum and quality control is very strong. This is to say that no curriculum can be adequately covered without adequate educational facilities and nobody will dream of quality when the curriculum is not well-covered.

On the appraisal of teacher's performance in Ebonyi state public secondary schools, the result of this study revealed that they are not adequately appraised. The consequence of not appraising teachers' performance adequately in public secondary schools cannot be overemphasized because it has been said time without number that no education system can rise above the quality of its teachers. It is in the light of the above that Nworgu (2010) posit that the only way to achieve quality instruction in the school system is to expose the personnel in the schools to regular evaluation programmes.

Finally, on how disciplinary actions are carried out to control staff in Ebonyi state public secondary schools. The findings showed that they are not adequate. A situation where principals shy away from sanctioning erring staff, bringing up matters that border on discipline to the disciplinary committee or at worst recommending appropriate disciplinary measures against recalcitrant staff to school board for disciplinary action leave much to be desired. Odanwu (2015) observed that in Ebonyi state public secondary schools, some teachers are seen as sacred cow by principal as they flaunt school rules and regulations and yet go unpunished. This according to her has led to the increasing cases of examination malpractices, cultism, sexual harassment, exploitation and other vices rampant in public secondary schools nowadays. The implication of these to the quality of education receive in public secondary schools could be better imagined than seen.

\section{Conclusion}

The study in the bid to examine the quality control measures put in place for quality assurance in public secondary schools in Ebonyi state was able to show in clear terms that these measures are not adequate and at times none existing. The implication of the present quality condition of education in public secondary schools is the seemingly decline in standard as is evident by the poor performance of students in external examinations such as senior secondary school certificate examinations and JAMB examination. It is therefore necessary that all hands must be on deck to see that the desired environment could be provided in public secondary schools to guarantee quality assurance and overall development of the society.

\section{Recommendations}

Based on the findings of this study, the following recommendations were made:

1) Federal and state inspectorate services of the ministry of education should ensure regular supervision and monitoring of secondary schools to ensure their total compliance with the minimum standards.

2) Secondary Education Board (SEB) should ensure that adequate educational facilities are provided in public secondary schools.

3) SEB should also organize regular training programmes for teachers for their professional growth and overall improvement of instructional delivery in public secondary schools.

4) Principals should provide friendly atmosphere in their schools as well as use appropriate disciplinary measures to control staff instead of being aloof.

5) Private partnership participation in the provision of public secondary education should be sought and or encouraged by the government.

\section{References}

[1] Afianmagbon, B.E.; Nwokocha, L.K.; Igbineweka, V.O. and Okunamiri, P.O. (2009). Maximizing teacher's effectiveness through conference and conceptual innovative supervisory techniques. A paper presented at the annual conference of NAEAP held at Nnamdi Azikiwe University, Awka Anambra state.

[2] Azih, N.C. (2008). An appraisal of teachers and teaching facilities available for teaching business studies in secondary schools in Abakaliki urban. Business Education Journal 6(2) 135-142.

[3] Fadokun, J.B. (2004). Total quality management: A sine qua non for effective schools management in the $21^{\text {st }}$ century. Unpublished conference proceeding of the institute of education Onabanjo University Ago-Iwoye, Ogun State.

[4] Federal Republic of Nigeria (FRN, 2004). National Policy on Education. Abuja: NERDC.

[5] Federal Ministry of Education (2009). The state of education in Nigeria. Abuja: Federal Inspectorate Services FMOE.

[6] Maduemere, O.C. (2004). Managing staff for quality assurance in secondary education sector. In B.A. Echiazu and M.U.O Ivowi (eds) minimum standard and accountability in the Nigeria education system. Nigeria academy of education conference proceedings.

[7] Nworgu, B.G. (2010). Training manual on effective implementation of Continuous Assessment. Nsukka: University Trust Publishers.

[8] Ocho, L.O. (2010). Qualitative education for all round development: setting task for the new catholic education system. A paper presented at the Enugu Diocesan C.M.O annual seminar held at NRACC, Emene- Enugu.

[9] Odanwu, J.C. (2015). Quality control measures in Ebonyi State secondary schools. Unpublished P.hD thesis Ebonyi State University, Abakaliki. 


\section{International Journal of Science and Research (IJSR) \\ ISSN (Online): 2319-7064}

Index Copernicus Value (2013): 6.14 | Impact Factor (2015): 6.391

[10] Ogba, F.N. (2011). Human resource management in secondary schools in Ebonyi state. Unpublished P.hD Dissertation Ebonyi State University, Abakaliki.

[11] Omoregie, E.O. (2005). Comparative study of quality and quantity of teachers and facilities in public and private schools in Esan West Local Government Area of Edo State. Nigerian Journal of Educational Administration and Planning 5(2) 201-209.

[12] Oyedeji, N.B. and Fasasi, Y.A. (2006). Dynamics of Administrative Leadership. In J.B. Babalola, A.O. Oyeni, S.O. Adedeji, A.A. Suleiman and M.O. Arikewuyo (eds). Educational Management: Thoughts and Practice. Ibadan: Codat Publications.

Volume 5 Issue 7, July 2016 www.ijsr.net 